\title{
CO-PRODUCTION OF LACTIC ACID AND ETHANOL USING RHIZOPUS SP. FROM HYDROLYZED INEDIBLE CASSAVA STARCH AND LEAVES
}

\author{
Azlin SuHada Azmi", Nurlisa Yusuf, Dzun Noraini Jimat, \\ AND NOOR ILLI MOHAMAD PUAD \\ Department of Biotechnology Engineering, \\ Faculty of Engineering, International Islamic University Malaysia, \\ Jalan Gombak, 53100, Kuala Lumpur, Malaysia. \\ "corresponding author: azlinsu76@iium.edu.my \\ (Received: $5^{\text {th }}$ Jan. 2016; Accepted: 19 th Aug. 2016; Published online: $30^{\text {th }}$ Nov. 2016)
}

\begin{abstract}
Production of lactic acid and ethanol from inedible cassava starch and leaves was investigated. Prior to fermentation, hydrolysis of the starch and leaves was conducted. Hydrolysis was optimized by manipulating at three levels each four particular factors, namely acid concentration, starch concentration, temperature, and reaction time. Maximum glucose yield of $0.96 \mathrm{~g} / \mathrm{g}$ was obtained when $2.5 \%(\mathrm{w} / \mathrm{v})$ of cassava leaves with $2.5 \%(\mathrm{w} / \mathrm{v})$ of starch was hydrolyzed using $0.20 \mathrm{M}$ nitric acid at $160{ }^{\circ} \mathrm{C}$ of temperature for $10 \mathrm{~min}$. The potential of hydrolyzed cassava starch and leaves was then investigated for lactic acid production using fungal Rhizopus sp. The fermentation process was then conducted in a shake flask by varying four factors at three levels each. Maximum lactic acid and ethanol yields of $0.95 \mathrm{~g} / \mathrm{g}$ and $0.52 \mathrm{~g} / \mathrm{g}$, respectively, were achieved at different optimum conditions. Lactic acid production was found to be linked to a decrease in ethanol production. Design Expert v6.0.8 was used to aid in the design of the experiment using Taguchi's methodology.
\end{abstract}

ABSTRAK: Pengeluaran asid laktik dan etanol dari kanji dan daun ubi kayu tidak boleh dimakan telah dikaji. Sebelum penapaian, hidrolisis kanji dan daun telah dijalankan. Hidrolisis telah dioptimumkan dengan memanipulasi pada tiga peringkat setiap empat faktor tertentu, iaitu kepekatan asid, kepekatan kanji, suhu, dan masa tindak balas. Hasil glukosa maksimum $0.96 \mathrm{~g} / \mathrm{g}$ dihasilkan bila $2.5 \%$ (w/v) daun ubi kayu telah dihidrolisiskan dengan 2.5\% (w/v) kanji menggunakan $0.20 \mathrm{M}$ asid nitrik pada suhu 160 ${ }^{\circ} \mathrm{C}$ selama $10 \mathrm{~min}$. Potensi kanji dan daun ubi kayu dihidrolisis kemudiannya disiasat untuk pengeluaran asid laktik dengan menggunakan kulat Rhizopus sp. Proses penapaian kemudian dijalankan di dalam kelalang bergoncang dengan mengubah empat faktor di setiap tiga tahap. Hasil maksimum asid dan etanol laktik adalah sebanyak $0.95 \mathrm{~g} / \mathrm{g}$ dan $0.52 \mathrm{~g} / \mathrm{g}$, masing-masing, telah dicapai pada keadaan optimum yang berbeza. Pengeluaran asid laktik didapati mempunyai kaitan dengan pengurangan pengeluaran etanol. Design Expert v6.0.8 telah digunakan untuk membantu dalam reka bentuk eksperimen menggunakan kaedah Taguchi.

KEYWORDS: cassava leaves; cassava starch; ethanol; lactic acid; Rhizopus sp.

\section{INTRODUCTION}

Numerous investigations on the development of biotechnological processes for lactic acid production have been performed to make the process both more efficient and economical. One attempt has been made to start production with cheap raw materials, for 
the economical production of lactic acid with low levels of contaminants, high production rate and yield, fermentation with little or no pre-treatment, and year-round availability [1]. Among starchy materials, cassava root is one of the candidates suitable for lactic acid production. It is cheap, has year-round availability, and is a high and efficient carbohydrate producer under suboptimal conditions of uncertain rainfall, infertile soil, and limited input encountered in the tropics [2].

Cassava leaves are one of the byproducts from the cassava root harvesting process. Their yield can amount to as much as 60 tons of wet leaves or 12 tons of dried leaves per hectare [3]. The leaves are usually discarded as waste after harvesting the roots, which are themselves under-researched and under-utilized. Depending on the varieties, cassava leaves are rich in protein (14-40\% dry matter), vitamin B1, B2, C and carotenes [4] and have a good amino acid content. They are also a good source of minerals, particularly calcium, magnesium, phosphorus, iron, and zinc [5]. These are the essential mineral sources for microorganism growth in a fermentation system. However, the leaves contain two cyanogenic glucosides, namely linamarin and lotaustralin. These compounds may be decomposed by linamarase, a naturally occurring enzyme in cassava, liberating hydrogen cyanide $(\mathrm{HCN})[6]$.

Fungal Rhizopus species have been recognized as potentially suitable candidates for lactic acid production. Rhizopus sp. has the ability to utilize starch-based materials [7, 8], although fungus such as Rhizopus oryzae preferred glucose compared to other carbon sources $[9,10]$. Rhizopus strains also grow better in nitrogen-limited environments than lactic acid producing bacteria [11]. Besides lactic acid, this fungus also produces ethanol, which may be beneficial later during the separation steps of these two products.

The use of cassava leaves as a co-substrate to cassava starch for fermentation has great advantages for the production of lactic acid. The starch is available all year round and the leaves have adequate content of minerals for lactic acid production with Rhizopus $\mathrm{sp}$. Thus, this study investigated the potential of inedible cassava starch and its leaves for lactic acid production and other byproducts such as ethanol using fungal Rhizopus sp. in the fermentation process. The objectives of this research were as follows: i) to optimize the hydrolysis process of cassava starch and leaves for the maximum production of glucose and ii) to optimize the fermentation process for the maximum production of lactic acid.

\section{MATERIALS AND METHODS}

\subsection{Preparation of Cassava Leaves and Starch}

Inedible cassava tubers and leaves were obtained from a cassava plantation in Selangor, Malaysia. The cassava tuber was peeled and washed with water and then cut into small pieces. It was then dried on perforated trays in a vacuum oven (Memmert, Germany) at $80{ }^{\circ} \mathrm{C}$ for 24 hours. Finally, the dried slices were grounded into powder and this powder was stored in a microwavable container for further use.

Cassava leaves were also dried in the vacuum oven at $80{ }^{\circ} \mathrm{C}$ for 24 hours to remove water and cyanide. After that, the dry leaves were ground into powder before storing in a container for further use.

\subsection{Hydrolysis Process}

A concentration of $2.5 \%(\mathrm{w} / \mathrm{v})$ of cassava leaves was mixed with varying concentrations of tuber starch from $1.5 \%$ to $3.5 \%$ (w/v). Nitric acid (Merck, USA) was also prepared at different concentrations $(0.12-0.20 \mathrm{M})$ for the hydrolysis process, which 
was conducted in an oven (Memmert, Germany) at different temperatures (140-180 ${ }^{\circ} \mathrm{C}$ ) for several minutes (10-30 min). The supernatant was then separated from the biomass, via centrifugation, in order to analyze the glucose using high performance liquid chromatography, HPLC (Waters, USA). Hydrolysates prepared at selected conditions were used for fermentation (section 2.4).

\subsection{Microorganism and Culture Conditions}

Rhizopus sp. was isolated from ragi tapai [12] and grown on potato dextrose agar (PDA) under an incubation temperature of $37^{\circ} \mathrm{C}$ for 7 days. The produced spores were collected, using L-loop, by shaving and extracting it with $25 \mathrm{ml}$ of sterilized distilled water and filtering the mixture through sterilized filter paper.

Urea and nitrogen-phosporus-potasium (NPK) at a ratio of 15-15-15 were prepared in distilled water at $0.8 \%$ and $0.09 \%$, respectively, in a $150 \mathrm{ml}$ shake flask. The medium was then sterilized at $121{ }^{\circ} \mathrm{C}$ for $30 \mathrm{~min}$ and later cooled to room temperature. After that, the spore suspension was inoculated in the medium and placed in an incubator shaker (Infors AG, Switzerland) at $37^{\circ} \mathrm{C}, 200 \mathrm{rpm}$, for $25 \mathrm{~min}$.

\subsection{Fermentation Process}

Prepared inoculum was added into the hydrolyzed medium from section 2.2 and the $\mathrm{pH}$ was adjusted to different values (5-7) using hydrochloric acid and sodium hydroxide (Merck, USA). Then, it was incubated at different agitation speeds (150-350 rpm) and temperatures $\left(25-35^{\circ} \mathrm{C}\right)$ in an incubator shaker (Infors AG, Switzerland). Fermentation took place within 5 days.

\subsection{Glucose, Lactic Acid, and Ethanol Analysis}

Concentrations of glucose, lactic acid, and ethanol were determined from the supernatants obtained from section 2.4 and were analyzed using Supelcogel C-610H column or IC-Pak ${ }^{\mathrm{TM}}$ Ion Exclusion column (Sigma-Aldrich, USA) with SH-1011P precolumn (Sigma-Aldrich, USA) on an HPLC equipped with a refractive index (RI) detector. The column was eluted at $75^{\circ} \mathrm{C}$ with $0.5 \mathrm{mM}$ sulfuric acid at $1.0 \mathrm{ml} \cdot \mathrm{min}^{-1}$. The glucose yield, $X$, was based on Eq. (1):

$$
X=\frac{G}{1.11 \cdot S}
$$

where $G$ is the glucose concentration from the hydrolysis process and $S$ is the starch concentration. The value of 1.11 is the correction factor as a result of the increase in total solids during glucose production [13]. Yields of lactic acid and ethanol were based on Eq. (2).

$$
\text { Yield }=\frac{\text { Lactic acid or ethanol concentration }(g / l)}{\text { Initial glucose concentration }(g / l)}
$$

\subsection{Design of Experiment (DOE)}

A standard orthogonal array of L9 $\left(3^{4}\right)$ was selected to examine a four-factor system. The L9 $\left(3^{4}\right)$ array consisted of 9 runs requiring a fraction of the full factorial design of 81 runs. All the runs in this work involved the corresponding combination of levels to which the factors in the experiment were set. The experimental results were analyzed to independently extract the main effects of the factors. 


\section{RESULTS AND DISCUSSION}

\subsection{Optimization of the Hydrolysis Process}

Table 1 shows an L9 orthogonal array of DOE for hydrolysis process using Taguchi methods. Taguchi methods were chosen for the experiment because they provide an alternative to standard factorial designs. From the table, the maximum and minimum glucose yields were obtained from run 2 and run 7, respectively. The maximum and minimum values were respectively equivalent to $0.90 \mathrm{~g} / \mathrm{g}$ and $0.26 \mathrm{~g} / \mathrm{g}$ of starch-glucose conversion.

The maximum concentration was obtained when $2.5 \%(\mathrm{w} / \mathrm{v})$ of starch with $2.5 \%$ (w/v) leaves were hydrolyzed at a temperature of $140{ }^{\circ} \mathrm{C}$ using $0.16 \mathrm{M}$ of $\mathrm{HNO}_{3}$. The minimum concentration of glucose was obtained when $1.5 \%(\mathrm{w} / \mathrm{v})$ of starch with $2.5 \%$ (w/v) of leaves (fixed amounts for all runs) were hydrolyzed at same temperature $\left(140{ }^{\circ} \mathrm{C}\right)$ using $0.12 \mathrm{M}$ of $\mathrm{HNO}_{3} . \mathrm{HNO}_{3}$ was used in this study, to take the advantage of the nitrogen content from the acid for the later fermentation process.

Table 1: Glucose yield resulting from the hydrolysis of cassava starch and leaves

\begin{tabular}{cccccc}
\hline Run & $\begin{array}{c}\text { Acid } \\
\text { Concentration } \\
(\mathrm{M})\end{array}$ & $\begin{array}{c}\text { Starch } \\
\text { Concentration } \\
(\mathrm{w} / \mathrm{v} \%)\end{array}$ & $\begin{array}{c}\text { Temperature } \\
\left({ }^{\circ} \mathrm{C}\right)\end{array}$ & $\begin{array}{c}\text { Time } \\
(\mathrm{min})\end{array}$ & $\begin{array}{c}\text { Yield } \\
(\mathrm{g} / \mathrm{g})\end{array}$ \\
\hline 1 & 0.16 & 1.5 & 180 & 20 & 0.47 \\
2 & 0.16 & 2.5 & 140 & 30 & 0.90 \\
3 & 0.14 & 3.5 & 140 & 20 & 0.69 \\
4 & 0.14 & 2.5 & 180 & 10 & 0.87 \\
5 & 0.14 & 1.5 & 160 & 30 & 0.44 \\
6 & 0.12 & 2.5 & 160 & 20 & 0.76 \\
7 & 0.12 & 1.5 & 140 & 10 & 0.26 \\
8 & 0.12 & 3.5 & 180 & 30 & 0.52 \\
9 & 0.16 & 3.5 & 160 & 10 & 0.76 \\
\hline
\end{tabular}

Table 2: ANOVA for the selected factorial model for optimization of the hydrolysis process

\begin{tabular}{cccccc}
\hline Source & $\begin{array}{c}\text { Sum of } \\
\text { squares }\end{array}$ & $\begin{array}{c}\text { Degree of } \\
\text { freedom }\end{array}$ & $\begin{array}{c}\text { Mean } \\
\text { square }\end{array}$ & F Value & Prob>F \\
\hline Model & 0.38 & 6 & 0.063 & 210.12 & 0.0047 \\
Acid Conc.(A) & 0.064 & 2 & 0.032 & 106.78 & 0.0093 \\
Starch Conc.(B) & 0.31 & 2 & 0.16 & 519.11 & 0.0019 \\
Temp.(C) & $2.467 \mathrm{E}-3$ & 2 & $1.233 \mathrm{E}-3$ & 4.11 & 0.1957 \\
Residual & $6.00 \mathrm{E}-4$ & 2 & $3.000 \mathrm{E}-4$ & & \\
Cor Total & 0.38 & 8 & & & \\
\hline
\end{tabular}

Std Dev. $=0.48 \quad \mathrm{R}-\mathrm{Sq}=99.84 \% \quad \mathrm{R}-\mathrm{Sq}(\operatorname{adj})=99.38 \% \quad$ Pred R-Square $=96.79 \%$

To analyze the hydrolysis process, analysis of variance (ANOVA) for the selected factorial model was conducted on the glucose yield and the results are presented in Table 2 . The analysis indicates that the model is significant, with two of the factors contributing significantly $(p<0.05)$ to the model. Concentration of starch was the most significant factor affecting glucose concentration followed by the concentration of acid. This was 
expected, since higher starch concentration resulted in higher glucose hydrolyzed from it. Maximum glucose concentration was obtained when $2.5 \%(\mathrm{w} / \mathrm{v})$ of cassava starch was used, and the concentration reduced when the starch concentration was at $3.5 \%(\mathrm{w} / \mathrm{v})$, as shown in Fig. 1. It may be concluded that the starch concentration of $2.5 \%(\mathrm{w} / \mathrm{v})$ is the optimum concentration for this study.
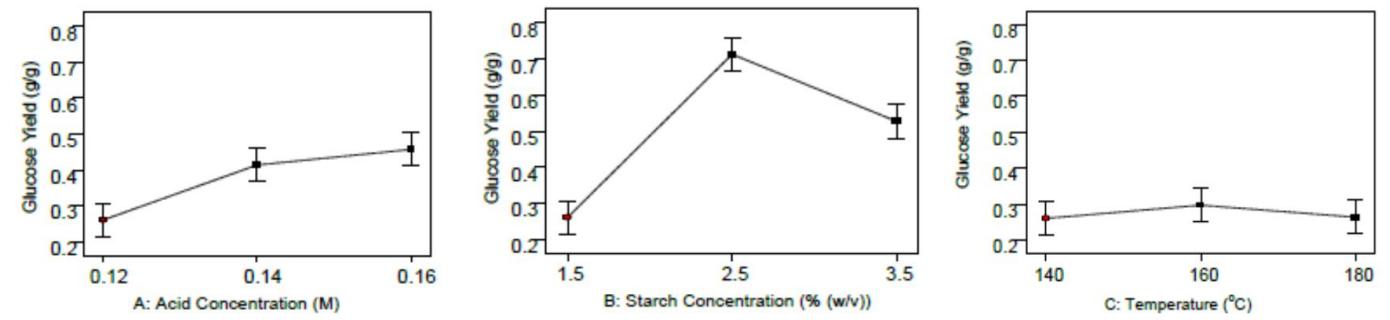

Fig. 1: One factor plots of glucose yield ( $\mathrm{g} / \mathrm{g}$ ) versus A: acid concentration (M), B: starch concentrations $(\%(\mathrm{w} / \mathrm{v}))$ and $\mathrm{C}$ : temperature $\left({ }^{\circ} \mathrm{C}\right)$, respectively.

Figure 1 shows that the glucose yield increased as the concentration of $\mathrm{HNO}_{3}$ increased. The optimum concentration of $\mathrm{HNO}_{3}$ was not determined at this stage. However, it was further analyzed using one-factor-at-time (OFAT) and the results are plotted in Fig. 2. The analysis was carried out at different acid concentrations ranging from $0.16 \mathrm{M}$ to $0.22 \mathrm{M}$, while other parameters were kept constant. The OFAT for the hydrolysis process was performed using equal amounts of cassava leaves and starch (i.e. $2.5 \%(\mathrm{w} / \mathrm{v})$ each), and hydrolyzed at a temperature of $160{ }^{\circ} \mathrm{C}$ for 10 minutes. These were the optimized values obtained during hydrolysis using the Taguchi method, as previously shown in Fig. 1. Hydrolysis time did not contribute to the model and did not significantly affect glucose yield. Thus, 10 min was selected for the OFAT analysis. The highest yield of glucose of $0.96 \mathrm{~g} / \mathrm{g}$ was later obtained at $0.20 \mathrm{M} \mathrm{HNO}_{3}$. This was an improved yield of $7 \%$ compared to that previously obtained at $0.90 \mathrm{~g} / \mathrm{g}$.

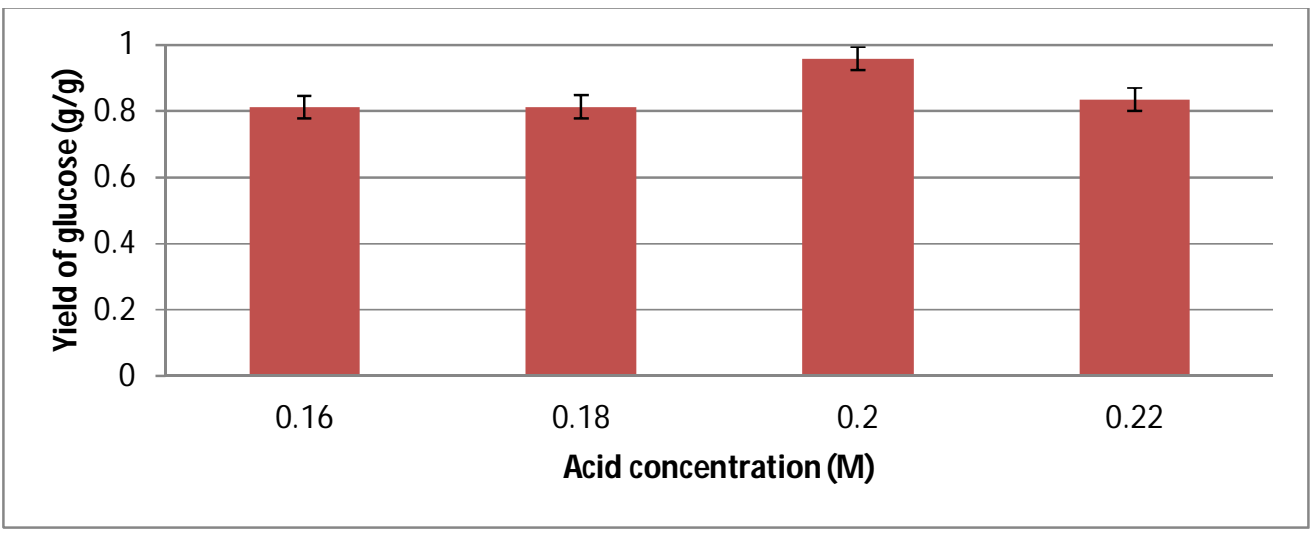

Fig. 2: Yield of glucose at different acid concentrations for OFAT analysis.

The hydrolysis process was validated to prove that the regression model is reliable. The hydrolysis process was done using two sets of process conditions, and the observed glucose concentration values were compared to predicted values for confirmation, as shown in Table 3. The percentage difference between actual and predicted values is $11 \%$ to $14 \%$; proving that the experiment is repeatable at an acceptable range. 
Table 3: Validation of the hydrolysis process

\begin{tabular}{|c|c|c|c|c|c|}
\hline \multirow[t]{2}{*}{ Run } & \multirow{2}{*}{$\begin{array}{c}\text { Acid } \\
\text { Concentration } \\
\text { (M) }\end{array}$} & \multirow{2}{*}{$\begin{array}{c}\text { Starch } \\
\text { Concentration } \\
(\mathrm{g}) \\
\end{array}$} & \multirow{2}{*}{$\begin{array}{c}\text { Temperature } \\
\left({ }^{\circ} \mathrm{C}\right) \\
\end{array}$} & \multicolumn{2}{|c|}{$\begin{array}{c}\text { Concentration of glucose } \\
(\mathrm{g} / \mathrm{l})\end{array}$} \\
\hline & & & & Actual & Predicted \\
\hline 1 & 0.14 & 2.5 & 160 & 22.01 & 25.01 \\
\hline 2 & 0.16 & 2.5 & 160 & 22.68 & 26.35 \\
\hline
\end{tabular}

\subsection{Optimization of the Fermentation Process}

\subsubsection{Lactic Acid Production}

Fermentation media consists of $2.5 \%(\mathrm{w} / \mathrm{v})$ cassava leaves that were prepared using optimized conditions from the hydrolysis process (hydrolyzed using $0.2 \mathrm{M} \mathrm{HNO}_{3}$ at a temperature of $160{ }^{\circ} \mathrm{C}$ for $10 \mathrm{~min}$ ). Rhizopus sp. was inoculated into the media for lactic acid production. To optimize the fermentation process, the design of experiment (DOE) consists of a L9 orthogonal array of Taguchi method analyzing four factors with three levels. The studied factors were $\mathrm{pH}$, inoculum size, temperature, and agitation speed. Maximum accumulation of lactic acid and ethanol concentrations were recorded as shown in Table 4. Generally, constant lactic acid concentrations were obtained after 36 hours of cultivation. The maximum yields of lactic acid and ethanol based on initial glucose concentration were obtained from run 2 and 4 at $0.95 \mathrm{~g} / \mathrm{g}$ and $0.52 \mathrm{~g} / \mathrm{g}$, respectively.

Table 4: Lactic acid and ethanol concentrations from nine set of runs.

\begin{tabular}{cccccccc}
\hline Run & $\mathrm{pH}$ & $\begin{array}{c}\text { Inoculum size } \\
(\text { spore/ml })\end{array}$ & $\begin{array}{c}\text { Agitation } \\
(\mathrm{rpm})\end{array}$ & $\begin{array}{c}\text { Temperature } \\
\left({ }^{\circ} \mathrm{C}\right)\end{array}$ & & $\begin{array}{c}\text { Lactic Acid } \\
(\mathrm{g} / \mathrm{g})\end{array}$ & Ethanol $(\mathrm{g} / \mathrm{g})$ \\
\cline { 1 - 1 } \cline { 7 - 8 } & 7 & $10^{4}$ & 150 & 35 & & 0.41 & 0.16 \\
2 & 5 & $10^{4}$ & 200 & 30 & & 0.95 & 0.02 \\
3 & 5 & $10^{3}$ & 150 & 25 & & 0.39 & 0.00 \\
4 & 7 & $10^{3}$ & 250 & 30 & & 0.29 & 0.52 \\
5 & 5 & $10^{5}$ & 250 & 35 & & 0.05 & 0.32 \\
6 & 6 & $10^{4}$ & 250 & 25 & & 0.23 & 0.23 \\
7 & 6 & $10^{3}$ & 200 & 35 & & 0.09 & 0.02 \\
8 & 7 & $10^{5}$ & 200 & 25 & & 0.06 & 0.06 \\
9 & 6 & $10^{5}$ & 150 & 30 & & 0.09 & 0.00 \\
\hline
\end{tabular}

The analysis of variance (ANOVA) for lactic acid of the selected factorial model is presented in Table 5. The model $F$-value implies that the model was significant. In this case, inoculum size (B) was the only significant model term with the lowest $p$-values $(0.0098)$ among the studied factors. Agitation and temperature of the fermentation process did not significantly affect lactic acid production. However, the optimum level may be determined from one factor plot of lactic acid with respect to inoculum dilution, agitation speed, and temperature (Fig. 3). From the figure, the optimum levels for inoculum size, agitation, and temperature were $10^{4} / \mathrm{ml}, 150 \mathrm{rpm}$, and $30^{\circ} \mathrm{C}$, respectively. 
Table 5: ANOVA for the selected factorial model for optimization of lactic acid yield

\begin{tabular}{cccccc}
\hline Source & $\begin{array}{c}\text { Sum of } \\
\text { squares }\end{array}$ & $\begin{array}{c}\text { Degree of } \\
\text { freedom }\end{array}$ & $\begin{array}{c}\text { Mean } \\
\text { square }\end{array}$ & F Value & Prob>F \\
\hline Model & 378.32 & 6 & 63.05 & 43.68 & 0.0225 \\
Ino. size (B) & 291.22 & 2 & 145.61 & 100.88 & 0.0098 \\
Agitation (C) & 33.25 & 2 & 16.62 & 11.52 & 0.0799 \\
Temp (D) & 53.85 & 2 & 26.93 & 18.66 & 0.0509 \\
Residual & 2.89 & 2 & 1.44 & & \\
Cor Total & 381.20 & 8 & & & \\
\hline Std Dev. $=1.20$ & $\mathrm{R}-\mathrm{Sq}=99.24 \%$ & $\mathrm{R}-\mathrm{Sq}(\mathrm{adj})=96.97 \%$ & Pred R-Squared $84.67 \%$
\end{tabular}


Fig. 3 One factor plots for lactic acid with respect to B: inoculum size, C: agitation speed, and D: temperature, respectively.

The maximum yield of lactic acid was attained with the initial inoculum size of $10^{4} / \mathrm{ml}$. The same result was also reported by others where maximum lactic acid was produced at low initial inoculum size; around $10^{3}-10^{4} / \mathrm{ml}[14,15]$. It was also reported that the size of inoculum influenced the morphology of the Rhizopus fungus [15-18]. When the size of the inoculum was below $10^{5} / \mathrm{ml}$, they produced a mycelia floc while larger sizes resulted in the formation of pellet or clump mycelia. In this study, mycelia floc was observed and the morphology might have influenced the oxygen transfer and produced different concentrations of lactic acid.

Rhizopus sp. requires oxygen supply during aerobic fermentation on order to produce lactic acid as the main product [19]. Agitation is important for proper distribution of oxygen in a shake flask. The agitation speed for Rhizopus sp. growth ranged from $100 \mathrm{rpm}$ to $400 \mathrm{rpm}$ [20]. Results obtained from this study have shown that the lowest agitation speed of $150 \mathrm{rpm}$ produced the maximum amount of lactic acid. This might be due to the sensitivity of Rhizopus sp. to agitation speed which also had been observed by Mohd Nasir et al. [21] and Tanyildizi et al. [22].

Rhizopus fungus can grow in a fermentation temperature ranging between 25 to $45{ }^{\circ} \mathrm{C}$ $[8,23,24]$. As with growth, lactic acid production is also dependent on the temperature. As previously mentioned, the optimum temperature for maximum lactic acid yield was at $30^{\circ} \mathrm{C}$. Similar results were also reported by Huang et al. [23, 25] when they fermented potato wastewater using Rhizopus arrhizus. In their study, biomass was decreased when temperature increased.

Control of initial $\mathrm{pH}$ is important for high lactic acid yield since $\mathrm{pH}$ value will drop during its production to around $\mathrm{pH} 2.4$ [25]. The $\mathrm{pH}$ is an important factor to be controlled and monitored in any fermentation process. Calcium carbonate is commonly added to neutralize lactic acid during fermentation. In this study, no neutralizing reagent was used. 
However, cassava leaves used in this study contained a detected amount of magnesium (5 $\times 10^{-3}-7.5 \times 10^{-3} \mathrm{~g} / \mathrm{g}$ ) in dried cassava leaves and traces of iron and zinc (data not shown). Magnesium might have some effect as a neutralizing agent and in controlling the $\mathrm{pH}$. However, it was found that $\mathrm{pH}$ had no significant effect on lactic acid yield in this study. Nevertheless, the range selected in this study ( $\mathrm{pH}$ value of 5.0 to 7.0) is the favorable $\mathrm{pH}$ range for high lactic acid yield $[8,23]$.

\subsubsection{Ethanol Production}

Unlike lactic acid bacteria, Rhizopus sp. also produces byproducts such as ethanol. The maximum and minimum yields of ethanol conversion were obtained from Runs 4 and 3 , respectively, as shown in Table 4. Generally, when ethanol production is high, lactic acid yield will be lower. The increase in lactic acid production was coupled with a reduction of biomass and byproducts [19].

Table 6: ANOVA for the selected factorial model for optimization of ethanol yield

\begin{tabular}{cccccc}
\hline Source & $\begin{array}{c}\text { Sum of } \\
\text { squares }\end{array}$ & $\begin{array}{c}\text { Degree of } \\
\text { freedom }\end{array}$ & $\begin{array}{c}\text { Mean } \\
\text { square }\end{array}$ & F Value & Prob>F \\
\hline Model & 0.49 & 6 & 0.082 & 25.74 & 0.0379 \\
pH(A) & 0.10 & 2 & 0.052 & 16.33 & 0.0577 \\
Agitation (C) & 0.36 & 2 & 0.18 & 57.39 & 0.0171 \\
Temp (D) & 0.022 & 2 & 0.011 & 3.48 & 0.2230 \\
Residual & $6.349 \mathrm{E}-3$ & 2 & $3.175 \mathrm{E}-3$ & & \\
Cor Total & 0.50 & 8 & & & \\
\hline
\end{tabular}

Std Dev. $=0.056 \mathrm{R}-\mathrm{Sq}=98.72 \% \quad \mathrm{R}-\mathrm{Sq}(\operatorname{adj})=94.89 \% \quad$ Pred R-Squared $74.11 \%$
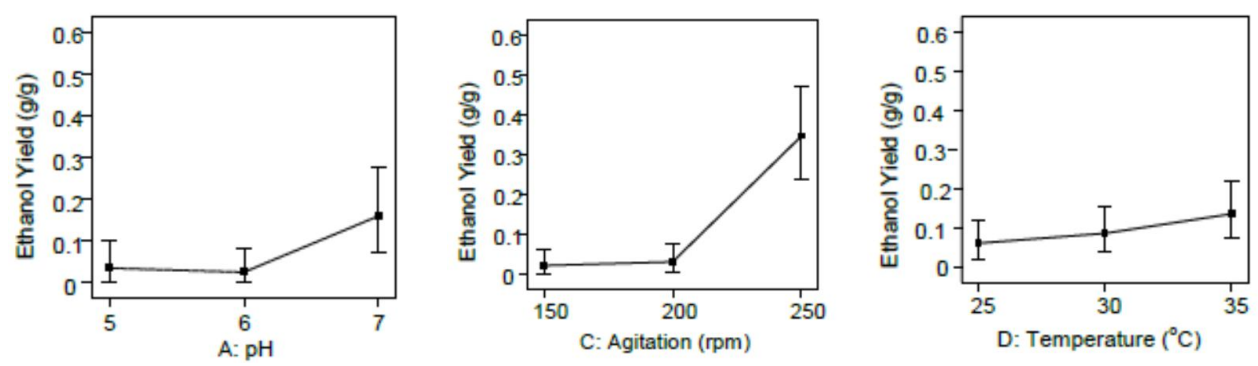

Fig. 4: One factor plots for ethanol with respect to A: $\mathrm{pH}, \mathrm{C}$ : agitation speed, and D: temperature, respectively.

ANOVA, as presented in Table 6 , shows that agitation was the only factor that significantly affected $(p<0.05)$ ethanol production. It is interesting to note that, the highest agitation of $250 \mathrm{rpm}$ produced the highest ethanol yield (Fig. 4). This was not expected, since ethanol has been reported to be produced more in the absence of oxygen or in oxygen-limited cultures $[11,19,26]$. However, this result coincided with lactic acid production where the lowest agitation produced the highest lactic acid yield. The only explanation of this phenomenon is that during high speed agitation, rapid oxygen utilization for initial growth of spores produced mycelia and rapidly reduced oxygen levels in the flask. In the shake flask, there was no aeration to supply oxygen. This created an anaerobic environment, or oxygen-limited environment, and produced more ethanol than lactic acid. Temperature and $\mathrm{pH}$ did not significantly affect ethanol production. However, from the graph shown in Fig. 4, maximum ethanol was achieved at a temperature of $35^{\circ} \mathrm{C}$ 
and a $\mathrm{pH}$ of 7 . As mentioned, there is an inverse relationship between lactic acid and ethanol production, as $35^{\circ} \mathrm{C}$ corresponds to the lowest lactic acid yield (Fig. 3).

\section{CONCLUSIONS}

Two process optimizations, namely hydrolysis and fermentation, were successfully performed using the Taguchi method. Glucose production was optimized for maximum yield through dilute acid hydrolysis. Four factors were studied: acid concentration, starch concentration, temperature, and reaction time, with optimized levels at $0.2 \mathrm{M}, 2.5 \%(\mathrm{w} / \mathrm{v})$, $160{ }^{\circ} \mathrm{C}$ and $10 \mathrm{~min}$, respectively. The same concentration of $2.5 \%(\mathrm{w} / \mathrm{v})$ cassava leaves was employed during the hydrolysis process. Fermentation was then optimized by varying four factors at three levels each for lactic acid and ethanol production. Factors were inoculum size, agitation speed, $\mathrm{pH}$, and temperature. Production of lactic acid had an inverse relationship with the production of ethanol which required a different culture environment for optimum yield. High yields of lactic acid were obtained at inoculum size, temperature, and agitation speed of $10^{4} / \mathrm{ml}, 30{ }^{\circ} \mathrm{C}$ and $150 \mathrm{rpm}$, respectively. On the other hand, maximum ethanol yield was attained at the temperature, agitation speed, and $\mathrm{pH}$ of $35^{\circ} \mathrm{C}, 250 \mathrm{rpm}$, and 7, respectively. This study shows the potential of using cassava leaves as one of the nutrient sources in microbial fermentation, while reducing waste accumulation problems caused by the root harvesting process.

\section{ACKNOWLEDGEMENTS}

The authors would like to thank Mr. Kok Keong Lim for supplying cassava raw materials for this research.

\section{REFERENCES}

[1] Wee Y-J, Kim J-N, Ryu H-W. (2006) Biotechnological production of lactic acid and its recent applications. Food Technol. Biotechnol.,44:163-72.

[2] Fregene M, Puonti-Kaerlas J. (2002) Cassava biotechnology. Cassava: Biology, production and utilization. 10:179-207.

[3] Lim KK. (2011) Project Consultant from Kibartek Sdn Bhd. 2011.

[4] Fasuyi AO. (2005) Nutrient composition and processing effects on cassava leaf (Manihot esculenta, Crantz) antinutrients. Pak J Nutr., 4:37-42.

[5] Ravindran V. (1992) Preparation of cassava leaf products and their use as animal feeds. Roots, tubers, plantains and bananas in animal feeding. FAO Animal Production and Health Paper.

[6] Cereda M, Mattos M. (1996) Linamarin: the toxic compound of cassava. J. Venomous Anim. Toxins., 2:6-12.

[7] Taskin M, Ortucu S, Unver Y, Arslan NP, Algur OF, Saghafian A. (2013) L-lactic acid production by Rhizopus oryzae MBG-10 using starch-rich waste loquat kernels as substrate. Starch - Stärke, 65:322-329.

[8] Zhang ZY, Jin B, Kelly JM. (2007) Production of lactic acid from renewable materials by Rhizopus fungi. Biochem. Eng. J., 35:251-263.

[9] Bulut S, Elibol M, Ozer D. (2004) Effect of different carbon sources on 1(+) -lactic acid production by Rhizopus oryzae. Biochem. Eng. J., 21:33-37.

[10] Park EY, Anh PN, Okuda N. (2004) Bioconversion of waste office paper to 1 (+)-lactic acid by the filamentous fungus Rhizopus oryzae. Bioresour. Technol., 93:77-83.

[11] Soccol C, Marin B, Raimbault M, Lebeault J-M. (1994) Potential of solid state fermentation for production of L (+)-lactic acid by Rhizopus oryzae. Appl. Microbiol. Biotechnol., 41:286-290. 
[12] Azmi AS, Ngoh CG, Mel M. (2013) Prediction of significant factors in the production of ethanol by ragi tapai co-culture using Taguchi methodology. Afr. J. Biotechnol., 10:18331841.

[13] Widiasa IN, Wenten IG. (2009) Saccharification of native cassava starch at high dry solids in an enzymatic membrane reactor. Reaktor, 12:129-136.

[14] Xiao Z, Wu M, Beauchemin M, Groleau D, Lau PC. (2011) Direct fermentation of triticale starch to lactic acid by Rhizopus oryzae. Ind. Biotechnol.,7:129-134.

[15] Büyükkileci AO, Hamamci H, Yucel M. (2006) Lactate and ethanol productions by Rhizopus oryzae ATCC 9363 and activities of related pyruvate branch point enzymes. J. Biosci. Bioeng., 102:464-466.

[16] Kossen N. (2000) The morphology of filamentous fungi. History of Modern Biotechnology II: Springer, 1-33.

[17] Liao W, Liu Y, Frear C, Chen S. (2007) A new approach of pellet formation of a filamentous fungus-Rhizopus oryzae. Bioresour. Technol., 98:3415-3423.

[18] Wu X, Jiang S, Liu M, Pan L, Zheng Z, Luo S. (2011) Production of L-lactic acid by Rhizopus oryzae using semicontinuous fermentation in bioreactor. J. Ind. Microbiol. Biotechnol., 38:565-571.

[19] Meussen BJ, de Graaff LH, Sanders JP, Weusthuis RA. (2012) Metabolic engineering of Rhizopus oryzae for the production of platform chemicals. Appl. Microbiol. Biotechnol., 94:875-886.

[20] Naranong N, Poocharoen D. (2001) Production of L-lactic acid from raw cassava starch by Rhizopus oryzae NRRL 395. The Kasetsart J (Nat Sci)., 35:164-170.

[21] Nasir NAM, Kamalbahrin MAM, Mohamad N, Anuar H, Mel M, Othman R (2011). Effect of Rhizopus oryzae fermentation on kenaf-based polylactic acid's Monomer. IIUM Eng. J.,12(4):83-87.

[22] Tanyıldızı MŞ, Bulut Ş, Selen V, Özer D. (2012) Optimization of lactic acid production with immobilized Rhizopus oryzae. Afr. J. Biotechnol.,11:8546-8552.

[23] Huang LP, Jin B, Lant P, Zhou J. (2005) Simultaneous saccharification and fermentation of potato starch wastewater to lactic acid by Rhizopus oryzae and Rhizopus arrhizus. Biochem. Engin. J., 23:265-276.

[24] Thongchul N, Navankasattusas S, Yang S-T. (2010) Production of lactic acid and ethanol by Rhizopus oryzae integrated with cassava pulp hydrolysis. Bioprocess and Biosystems Engineering, 33:407-416.

[25] Huang LP, Jin B, Lant P, Zhou J. (2003) Biotechnological production of lactic acid integrated with potato wastewater treatment by Rhizopus arrhizus. J. Chem. Technol. Biotechnol., 78:899-906.

[26] Skory CD. (2003) Induction of Rhizopus oryzae pyruvate decarboxylase genes. Curr. Microbiol., 47:59-64. 